\title{
EFFECT OF TURMERIC EXTRACT ON BLOOD PARAMETERS, FEED EFFICIENCY AND ABDOMINAL FAT CONTENT IN BROILERS
}

\author{
Sugiharto, Isroli, E. Widiastuti and N. S. Prabowo \\ Faculty of Animal Agriculture, Diponegoro University, \\ Tembalang Campus, Semarang 50275, Central Java - Indonesia \\ Corresponding E-mail: sgh undip@yahoo.co.id \\ Received January 06, 2011; Accepted Febraury 16, 2011
}

\begin{abstract}
The experiment was carried out to investigate the effect of turmeric extract on blood parameters, feed efficiency and abdominal fat content in broilers. A total of 100 mixed-sexes Lohman chicks were used in the experiment set up with completely randomized design of 5 different doses of turmeric extract given orally start from day- 15 to day-35. The chicks given no turmeric extract were used as a control (T0), whereas T1, T2, T3 and T4 were the chicks given turmeric extract of 200, 400, 600 and 800 $\mathrm{mg} / \mathrm{kg}$-live BW, respectively. Hemoglobin values of broilers given turmeric extract $800 \mathrm{mg} / \mathrm{kg}$-live BW was significantly higher $(p<0.05)$ at week-3 and week- 4 , but not at week-5, compared to broilers given turmeric extract with lower doses or control group. Turmeric extract did not affect significantly $(\mathrm{p}>0.05)$ the concentration of erythrocytes, the levels of hematocrit as well as FCR and abdominal fat content of broiler. Turmeric extract seemed to be able to improve the digestion and metabolism (of fat) resulted in enhanced production of hemoglobin in broilers. The hypolipidemic effect of turmeric that could hamper its potential to promote the growth of broilers per se might explain why turmeric could not improve the feed efficiency of broiler.

Keywords: abdominal fat, blood parameters, broiler, FCR, turmeric
\end{abstract}

\section{INTRODUCTION}

In many Asian countries including Indonesia the use of turmeric as a food spice, colorant and medicine has a long tradition (HMPC, 2009). It is traditionally accepted that turmeric is a potent antioxidant and anti-inflammatory agent ( $\mathrm{Pal}$ et al., 2001). It is also strongly alleged that turmeric can improve digestion and nutrient metabolism. The latter beneficial effects of turmeric are related to atsiri oil and curcumin content in turmeric (AlSultan and Gameel, 2004). Atsiri oil can improve the function of digestive tracts (small intestine) and stimulate the production of digestive enzymes resulting in improved digestion and increased nutrients metabolism (Darwis et al., 1991). Curcumin, in the form of curcuminoids (HMPC, 2009), can enhance bile production and hence fat digestion (Al-Sultan and Gameel, 2004). Being intended further specifically on fat metabolism, administration of turmeric in broiler is subjected to enhance the production of succinyl-CoA (formed in the Krebs metabolic cycle) which in turn is expected to increase the production of hemoglobin. This aim is motivated by the fact that the first step in heme (constituent of hemoglobin) synthesis takes place with the condensation of succinyl-CoA and glycine (Bunn and Forget, 1986).

Application of turmeric in broiler is usually carried out by including this substance in the diets (Kusumaningsih, 2001; Al-Sultan and Gameel, 2004). With the aims to improve the effectiveness of turmeric, the preliminary study found that administration of turmeric (in the form of extract) orally to broilers three times a week at dose 400 $\mathrm{mg} / \mathrm{kg}$-live BW or less had no significant effect on blood parameters and abdominal fat content in broilers.

On the background above, this present paper, therefore, was subjected to investigate the effect of turmeric in the form of extract given orally to broilers at different doses (including higher doses than those of applied by the latter author) on blood parameters, feed efficiency and abdominal fat content in broilers.

\section{MATERIALS AND METHODS}

Animals, Diets and Management Practices The experiment was performed of which 
used 100 mixed-sex Lohman chicks (MB 202 Platinum). All chicks were fed ad libitum with the same diets, commercial diets divided into starter diet (day-0 to day-21) and finisher diet (day-22 to day-35) (see Table 1). Turmeric extract was made by adding water into turmeric powder (meal), it was then stirred up and sedimented. The water was then thrown out. These processes were repeated many times until the water (above the sediment) became clear. The remained turmeric was then aerated indoor. The dried turmeric extract, based on the dose adjusted weekly, was then inserted in the capsule.

The experiment was principally set up based on completely randomized design. It was initiated by raising communally one-day-old chicks until day-14. At day-15 the chicks were randomly divided into 5 treatment groups with 4 replicates ( 5 chicks in each) until day-35. The turmeric extract was orally administrated to the chicks three times a week start from day-15 until day- 35 . The experimental treatments (the doses of the turmeric extract given to the chicks) were T0: the chicks given no turmeric extract (as a control), T1: the chicks given turmeric extract of 200 $\mathrm{mg} / \mathrm{kg}$-live BW, T2: the chicks given turmeric extract of $400 \mathrm{mg} / \mathrm{kg}$-live BW, T3: the chicks given turmeric extract of $600 \mathrm{mg} / \mathrm{kg}$-live $\mathrm{BW}$, and T4: the chicks given turmeric extract of 800 $\mathrm{mg} / \mathrm{kg}$-live BW.

All chicks were raised in a well ventilated laboratory broiler house from day- 0 until harvest time. Temperature and humidity were recorded daily at $6.00 \mathrm{am}, 12.00$ and $17.00 \mathrm{pm}$. The lights were on $24 \mathrm{~h}$ a day for the first 3 days, followed by $21 \mathrm{~h}$ light and $3 \mathrm{~h}$ dark thereafter. Management practices in general were similar for all treatment groups.

\section{Blood Parameters}

At week-2, 3, 4 and 5, $2 \mathrm{ml}$ blood was collected from wing vein of broilers and was then put in EDTA-prepared-vacutainer. Measurement of hemoglobin was performed using hemometer. Erythrocyte was counted using Improved Neubauer whereas hematocrit was measured using haemocytometer.

\section{Performances of Broiler and Abdominal Fat}

All chicks were weighed weekly from day- 0 until day-35, thus weight gain can be calculated. Feed intakes were also recorded weekly for each group. FCR was derived as feed consumed divided by weight gained. One bird per treatment
Table 1. Chemical Analysis of the Experimental Diets $\left.{ }^{*}\right)$

\begin{tabular}{lcc}
\hline Nutrients & $\begin{array}{c}\text { Starter Diet } \\
(\%)\end{array}$ & $\begin{array}{c}\text { Finisher Diet } \\
(\%)\end{array}$ \\
\hline Dry matter & 87.00 & 87.00 \\
Crude protein & 21.00 & 19.00 \\
Total fat & 5.00 & 5.00 \\
Crude fiber & 5.00 & 5.00 \\
Ash content & 7.00 & 7.00 \\
Ca & 0.90 & 0.90 \\
$\mathrm{P}$ & 0.60 & 0.60 \\
\hline
\end{tabular}

*)Data were obtained from the feed manufacture

group with same sex was slaughtered and eviscerated after being weighed out at day- 35 . Abdominal fat (considered as the fat from the proventriculus surrounding the gizzard down to the cloaca and adjacent to the abdominal muscle) was taken out and weighed. Abdominal fat was then expressed as a percentage of live BW.

\section{Statistical Analysis}

Data were assessed statistically using oneway analysis of variance (ANOVA). After a significant $F$ test $(\mathrm{p}<0.05)$, Duncan's multiple range test (DMRT) was used to investigate the differences among group means (Steel dan Torrie, 1987). All analysis were performed by SPSS 15.0 for Windows. A P-value of less than 0.05 was considered statistically significant.

\section{RESULTS AND DISCUSSION}

\section{Blood Parameters}

Hemoglobin values were significantly different $(\mathrm{p}<0.05)$ among treatment groups after turmeric extract administration (at week-3 and week-4, but not week-5). These findings also revealed that dose of turmeric extract $800 \mathrm{mg} / \mathrm{kg}$ live BW administrated orally was able to promote the production of hemoglobin in broiler (Table 2). Although our methods in administrating turmeric to broilers were different to Emadi et al. (2007) and Kumari et al. (2007), our findings were in concurrence to these previous authors. We prepared turmeric extract in the capsule and gave orally to broilers only three times a week start from day-15 until day-35, while those two authors included turmeric in the diet (as feed mixture) and administrated in daily basis throughout the 
Table 2. Value of Hemoglobin of Broiler Fed Diets Containing Turmeric Extract at Week-2 to Week-5

\begin{tabular}{|c|c|c|c|c|c|}
\hline Week & T0 & $\mathrm{T} 1$ & $\mathrm{~T} 2$ & $\mathrm{~T} 3$ & $\mathrm{~T} 4$ \\
\hline & \multicolumn{5}{|c|}{ 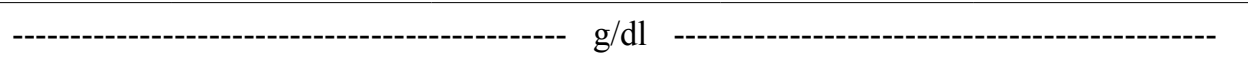 } \\
\hline 2 & $8.05 \pm 1.42$ & $7.00 \pm 0.82$ & $6.45 \pm 0.53$ & $8.40 \pm 2.08$ & $7.00 \pm 0.82$ \\
\hline 3 & $5.75 \pm 0.38^{\mathrm{a}}$ & $5.90 \pm 0.74^{\mathrm{a}}$ & $5.75 \pm 0.30^{\mathrm{a}}$ & $5.50 \pm 0.60^{\mathrm{a}}$ & $7.00 \pm 0.75^{\mathrm{b}}$ \\
\hline 4 & $6.95 \pm 1.19^{\mathrm{a}}$ & $8.20 \pm 0.52^{\mathrm{ab}}$ & $8.95 \pm 1.71^{\mathrm{ab}}$ & $9.80 \pm 1.33^{\mathrm{bc}}$ & $11.95 \pm 1.50^{\mathrm{c}}$ \\
\hline 5 & $7.80 \pm 0.42$ & $8.70 \pm 1.23$ & $8.65 \pm 1.06$ & $8.60 \pm 1.14$ & $7.75 \pm 0.60$ \\
\hline
\end{tabular}

a-cMeans followed by different superscripts within the same row indicates statistically different $(p<0.05)$

experiment. Curcumin in turmeric can accelerate the emulsification of fat by stimulating the production of bile (Al-Sultan and Gameel, 2004) so that the digestion of fat will be more optimal. Optimized fat digestion will indirectly increase the provision of substrates for ß-oxidation or fat metabolism which eventually enhances the production of succinyl-CoA through Krebs metabolic cycle (Cunningham and Klein, 2007). Considering succinyl-CoA is one of the materials needed for hemoglobin (heme in particular) synthesis (Bunn and Forget, 1986), enhanced succinyl-CoA production was therefore most likely to be followed by the increase of hemoglobin synthesis. Besides being affected by succinyl-CoA, hemoglobin value in broiler is also influenced by sex, age, strain, nutritional and physiological status, activities of broiler and environment (Parakkasi, 1986). It is well acknowledge that older birds are more susceptible to heat stress compared to younger ones. Aside from tropical temperature (average diurnal temperature and humidity during the experiment were $28.67^{\circ} \mathrm{C}$ and $80.92 \%$ ) that often induces heat stress; enhanced $\beta$-oxidation due to turmeric extract administration was also most likely to promote the production of heat (increment) in broiler. One of the mechanisms to dissipate heat from the body is by panting (thermal panting), increased respiratory rate with a decreased tidal volume (Ludders, 2004). Study by Comito et al. (2007) reported that thermal panting could decrease hemoglobin synthesis. On this background, no significant effect of turmeric extract on hemoglobin values on week- 5 could be accepted since the production of hemoglobin in the turmeric extract-treated-birds was hampered by panting activities in broilers due to over heat load. These results were also supported by
Basavaraj et al. (2011) who reported that the effect of turmeric on hemoglobin value was less significant under thermal stress.

Turmeric extract did not affect significantly $(p>0.05)$ the concentration of erythrocytes in the blood of broilers in our study (Table 3). In agreement to our findings, very recent study in broiler rabbits conducted by Basavaraj et al. (2011) also reported the same things. The principal component of erythrocytes is hemoglobin, which makes up about one-third of the erythrocytes content (Reece, 2009). Thus, enhanced hemoglobin concentration due to turmeric extract should be followed by the enhanced erythrocytes concentration. However, the findings above did not show this pattern. This discrepancy can be explained by the fact that the production of erythrocytes is not entirely correlated with the synthesis of hemoglobin (Fogiel, 2004). Immature erythrocytes cells (reticulocytes) have been able to produce hemoglobin. Hemoglobin produced subsequently circulates into vascular system whereas reticulocyte itself still experienced the developmental processes and, later on, mature in red bone marrow before being circulated into blood stream. As a result there is a possibility of divergence between erythrocytes and hemoglobin production (Guyton, 1991; Fogiel, 2004).

Hematocrit measures the percentage of the volume of whole blood that is made up of red blood cells (Reece, 2009). Hematocrit is strongly affected by red blood cells concentration in the blood. Thus, alongside with the concentration of erythrocytes, turmeric extract administration having no significant effect $(\mathrm{p}>0.05)$ on hematocrit level (Table 4) could be accepted. This result was concomitant to Emadi et al. (2007) who reported that inclusion of turmeric had no significant effect on hematocrit level of broiler 
Table 3. Concentration of Erythrocytes of Broiler Fed Diets Containing Turmeric Extract at Week-2 to Week-5

\begin{tabular}{|c|c|c|c|c|c|}
\hline Week & T0 & $\mathrm{T} 1$ & $\mathrm{~T} 2$ & $\mathrm{~T} 3$ & $\mathrm{~T} 4$ \\
\hline & \multicolumn{5}{|c|}{ - $106 / \mathrm{mm}^{3}$} \\
\hline 2 & $1.59 \pm 0.23$ & $1.54 \pm 0.48$ & $1.60 \pm 0.51$ & $1.21 \pm 0.32$ & $1.20 \pm 0.27$ \\
\hline 3 & $1.74 \pm 0.53$ & $1.97 \pm 0.54$ & $1.49 \pm 0.68$ & $1.34 \pm 0.68$ & $1.83 \pm 0.45$ \\
\hline 4 & $2.03 \pm 0.65$ & $1.92 \pm 0.68$ & $1.76 \pm 0.75$ & $2.03 \pm 0.30$ & $1.93 \pm 0.52$ \\
\hline 5 & $2.35 \pm 0.68$ & $1.85 \pm 0.87$ & $1.96 \pm 0.63$ & $1.68 \pm 0.08$ & $1.59 \pm 0.28$ \\
\hline
\end{tabular}

Table 4. Hematocrit Levels of Broiler Fed Diets Containing Turmeric Extract at Week-2 to Week-5

\begin{tabular}{|c|c|c|c|c|c|}
\hline Week & T0 & $\mathrm{T} 1$ & $\mathrm{~T} 2$ & T3 & $\mathrm{T} 4$ \\
\hline & \multicolumn{5}{|c|}{ 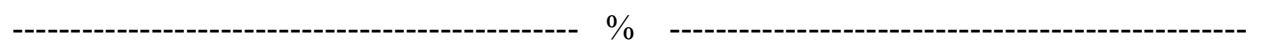 } \\
\hline 2 & $19.50 \pm 3.32$ & $20.25 \pm 2.75$ & $18.75 \pm 1.71$ & $21.00 \pm 2.94$ & $19.25 \pm 2.50$ \\
\hline 3 & $18.50 \pm 2.38$ & $18.25 \pm 1.26$ & $19.50 \pm 0.58$ & $18.67 \pm 1.15$ & $19.75 \pm 1.26$ \\
\hline 4 & $23.25 \pm 1.50$ & $24.00 \pm 2.16$ & $27.25 \pm 5.74$ & $25.75 \pm 0.96$ & $24.50 \pm 1.29$ \\
\hline 5 & $21.50 \pm 1.73$ & $21.75 \pm 1.71$ & $25.25 \pm 5.50$ & $24.75 \pm 3.77$ & $21.75 \pm 3.50$ \\
\hline
\end{tabular}

measured at day-21 and day-42. This study was actually aimed to improve the effectiveness of turmeric by processing it into extract, encapsulating and administrating orally to broilers. Again, different from Emadi et al. (2007) who administrated turmeric in daily basis, in this study the turmeric extract was given three times a week to broilers. Therefore, it might be decent to suggest that the quantity of turmeric extract, perhaps, was not sufficient to alter the metabolic and physiological processes influencing erythropoiesis which eventually affected hematocrit level.

\section{Feed Efficiency and Abdominal Fat Content}

Turmeric administration in broiler was actually hoped to be able to enhance the metabolism (Al-Sultan and Gameel, 2004) that later on could improve feed efficiency of broilers. However, our finding showed that FCR was not affected significantly $(\mathrm{p}>0.05)$ by turmeric extract administrated orally to broiler (Table 5). This results were in accordance with Emadi and Kermanshahi (2006) but in contrast to Durrani et al. (2006) who reported that turmeric improved feed efficiency of broiler at starter and finisher phase. Moreover, in agreement to our results, the study done by Basavaraj et al. (2010) reported that supplementation of turmeric powder did not alter FCR of broiler rabbit. The insignificant effect of turmeric on FCR of broilers was associated with the final BW and total feed intake that were apparently not affected by turmeric administration (data not shown).

The abdominal fat percentage showed no significant difference $(\mathrm{p}>0.05)$ between treatment groups in our study (Table 5). This finding favorably compared to earlier report of Mehala and Moorthy (2008). Nevertheless, this results numerically suggested that the abdominal fat percentage was lower with increasing the doses of turmeric extract administrated. Concomitant to the results, Kusumaningsih (2001) and Emadi and Kermanshahi (2006) reported that turmeric could reduce abdominal fat content of broilers by regulating the enzymes activities related to fat metabolism and by adjusting blood lipid metabolism (Zhong-ze et al., 2007). With respect to lipid metabolism in the body of broiler, study of Asai and Miyazawa (2001) in rats suggested that dietary curcuminoids affected fatty acids catabolism in the liver in a greater extent compared to de novo synthesis of fatty acids. Similarly, Ejaz et al. (2009) reported that curcumin supplementation increased fatty acids oxidation and reduced fatty acids esterification, 
Table 5. FCR and Abdominal Fat of Broilers Fed Diets Containing Turmeric Extract at Day-35

\begin{tabular}{lccccc}
\hline \multicolumn{1}{c}{ Week } & T0 & T1 & T2 & T3 & T4 \\
\hline FCR & $1.89 \pm 0.11$ & $1.92 \pm 0.04$ & $1.87 \pm 0.12$ & $1.85 \pm 0.04$ & $1.85 \pm 0.02$ \\
Abdominal fat (\%) & $2.07 \pm 0.43$ & $1.75 \pm 0.51$ & $1.49 \pm 0.54$ & $1.46 \pm 0.16$ & $1.17 \pm 0.21$ \\
\hline
\end{tabular}

resulting in net catabolism in adipose tissue. Furthermore, a DNA microarray study conducted by Honda et al. (2006) revealed that the changes in gene expression were considered to be the mechanism by which the turmeric affected the control of abdominal adipose tissue masses. Turmeric up-regulated the expression of genes related to B-oxidation in the liver of broilers. Apart from the metabolism occurred in the liver, reduced abdominal fat in broilers due to turmeric might also be contributed by the effect of curcumin (contained in turmeric) on adipocyte apoptosis. The TUNEL (Terminal Transferase dUTP Nick End Labeling) assay performed by Ejaz et al. (2009) revealed that increasing doses of curcumin remarkably induced apoptosis of adipocytes. Eventually, the potential of turmeric to partition of energy into lean rather than into fat tissue might attenuate the potential of turmeric in promoting the growth of broilers per se that we expected previously. Therefore, although turmeric administration did not improve the performances of broilers, turmeric may produce higher quality of broiler meat with lower fat content.

Although most authors suggest that turmeric is safe to be used as feed additives, the incidents of liver toxicity should be considered primarily in large doses of turmeric (HMPC, 2009). Beside dose, the toxic effect of turmeric seems also to depend on animal species and duration of treatment (Al-Sultan and Gameel, 2004). Since the application of the doses of turmeric extract from low to relatively high dose, therefore, to avoid the incidents of liver toxicity in the experimental birds, it is administrated for turmeric only three times a week instead of in daily basis. It is also administrated for turmeric extract only in the finisher phase (start from day-15 until day35 ), not throughout the experiment.

\section{CONCLUSION}

Turmeric extract seemed to be able to improve the digestion and metabolism (of fat) resulted in enhanced production of hemoglobin in broiler, perhaps by stimulating the production of succinyl-CoA. Administration of turmeric extract increased fatty acids oxidation and reduced fatty acids esterification leading to reduced abdominal fat content of broiler. The hypolipidemic effect of turmeric might hamper its potential to promote the growth of broiler per se, as a result that turmeric could not improve the feed efficiency of broilers.

\section{REFERENCES}

Al-Sultan, S.I. and A.A. Gameel. 2004. Histopathological changes in the livers of broiler chicken supplemented with turmeric (Curcuma longa). Int. J. Poult. Sci. 3:333-336

Asai, A. and T. Miyazawa. 2001. Dietary curcuminoids prevent high-fat diet-induced lipid accumulation in rat liver and epididymal adipose tissue. J. Nutr. 131:2932-2935

Basavaraj, M., V. Nagabhushana, N. Prakash, S. Mallikarjunappa, M.M. Appannavar and P. Wagmare. 2010. Effect of dietary supplementation of Pulvis CurcumaLonga on the voluntary feed intake, nutrient digestibility and Growth performance of Broiler rabbits under summer stress. Veterinary World. 3:369-372

Basavaraj, M., V. Nagabhushana, N. Prakash, M.M. Appannavar, P. Wagmare and S. Mallikarjunappa. 2011. Effect of dietary supplementation of Curcuma Longa on the biochemical profile and meat characteristics of broiler rabbits under summer stress. Veterinary World. 4:15-18

Bunn, H.F. and B.G. Forget . 1986. Hemoglobin: Molecular, Genetic and Clinical Aspects. Saunders, Philadelphia

Comito, R.W., W.O. Reece, D. W. Trampel and K.J. Koehler. 2007. Acid-base balance of the domestic turkey during thermal panting. Poult. Sci. 86:2649-2652

Cunningham, J.G. and B.G. Klein. 2007. Veterinary Physiology: $4^{\text {th }}$ Ed. Saunders Elsevier 
Darwis, S. N., A. B. D. M. Indo dan S. Hasiyah. 1991. Tumbuhan obat famili Zingiberaceae. Badan Penelitian dan Pengembangan Pertanian, Bogor

Durrani, F.R., M. Ismail, A. Sultan, S. M. Suhail, N. Chand and Z. Durrani. 2006. Effect of Different Levels of Feed Added Turmeric (Curcuma longa) on the Performance of Broiler Chicks. JABS. 1:9-11

Ejaz, A., D. Wu, P. Kwan and M. Meydani. 2009. Curcumin inhibits adipogenesis in 3T3-L1 adipocytes and angiogenesis and obesity in C57/BL Mice ${ }^{1-3}$. J. Nutr. 139:1-7

Emadi, M. and H. Kermanshahi. 2006. Effect of turmeric rhizome powder on performance and carcass characteristic of broiler chickens. Int. J. Poult. Sci. 5: 1069-1072

Emadi, M., H. Kermanshahi and E. Maroufyan. 2007. Effect of varying levels of turmeric rhizome powder on some blood parameters of broiler chickens fed corn-soybean meal based diets. Int. J. Poult. Sci. 6:345-348

Fogiel, M. 2004. The Biology Problem Solver. Reseach and Education, Piscataway, New Jersey.

Guenther, E. 1948. Essentials oils Ernest Guenther. Van Nostrand, New York

Guyton, A. C. 1991. Textbook of Medical Physiology. $4^{\text {th }}$ Ed. Saunders, Philadelphia

HMPC (Committee on Herbal Medicinal Products). 2009. Assessment Report on Curcuma Longa L. Rhizoma. European Medicines Agency. London 12 November 2009. Doc. Ref.: EMEA/HMPC/456848/ 2008 (http://www.ema.europa.eu)

Honda, S., F. Aoki, H. Tanaka, H. Kishida, T. Nishiyama, S. Okada, I. Matsumoto, K. Abe and T. Mae. 2006. Effects of ingested turmeric oleoresin on glucose and lipid metabolisms in obese diabetic mice: A DNA microarray study. J. Agric. Food Chem.
54:9055-9062

Kumari, P., M.K. Gupta, R. Ranjan, K.K. Singh and R. Yadava. 2007. Curcuma longa as feed additive in broiler birds and its pathophysiological effect. IJEB. 45: 272-277

Kusumaningsih, S. 2001. Pemanfaatan kunyit (Curcuma domestica Val) dalam ransum broiler sebagai upaya menurunkan lemak abdominal dan kadar kolesterol. Thesis Program Studi Magister Ilmu Ternak Program Pascasarjana-Fakultas Peternakan Universitas Diponegoro, Semarang

Ludders, J. W. 2004. Respiration in birds. In: Dukes' Physiology of Domestic Animals. $12^{\text {th }}$ ed. W. O. Reece, ed. Cornell Univ. Press, Ithaca, NY. Pages 149-161

Mehala, C. and M. Moorthy. 2008. Effect of Aloe vera and Curcuma longa (Turmeric) on carcass characteristics and biochemical parameters of broilers. Int. J. Poult. Sci. 7:857-861

Pal, S., T. Choudhuri, S. Chattopadhyay, A. Bhattacharya, G.K. Datta, T. Das and G. Sa. 2001. Mechanisms of curcumin-induced apoptosis of Ehrlich's ascites carcinoma cells. Biochem. Biophys. Res. Commun. 288: 65865

Parakkasi, A. 1986. Ilmu Gizi dan Makanan Ternak Monogastrik. PT Angkasa, Bandung

Reece, W.O. 2009. Functional Anatomy and Physiology of Domestic Animals, $4^{\text {th }} \mathrm{Ed}$. Wiley-Blackwell.

Steel, R. G. D. and J. H. Torrie. 1987. Principles and Procedure of Statistics. A Biometrical Approach. $2^{\text {nd }}$ Ed. McGraw-Hill Co., New York.

Zhong-ze, H., H. Yuan-qing, W. Li-ke and W. Aiyou. 2007. Effect of curcumin on metabolism of fat for broilers. J. Anhui Sci. Technol. Univ. 6:1 (http://en.cnki.com.cn/Article_en/CJFD Total-ANJS200706001.htm) 